\title{
Ellipsis
}

2021

\section{When She Grows Up}

Caitlin B. Miller

Follow this and additional works at: https://scholarworks.uno.edu/ellipsis

\section{Recommended Citation}

Miller, Caitlin B. (2021) "When She Grows Up," Ellipsis: Vol. 46 , Article 12.

DOI: https://doi.org/10.46428/ejail.46.12

Available at: https://scholarworks.uno.edu/ellipsis/vol46/iss1/12

This Poetry is brought to you for free and open access by the Department of English and Foreign Languages at ScholarWorks@UNO. It has been accepted for inclusion in Ellipsis by an authorized editor of ScholarWorks@UNO. For more information, please contact scholarworks@uno.edu. 


\section{When she grows up by Caitlin B. Miller}

She wanted to be Cinderella. She said it proud, small voice reverberating the chapel at preschool graduation. Her parents took up the corner pew, sun cast white from windows over smile-anchored faces, cast white anchoredmemories overexposed in bright laughter.

But she didn't know that to become a princess she first must know suffering-

a lifetime's worth:

time takes advantage

of its own ebb, snatches

memories and loved ones.

In the brothers Grimm version of the tale, Cinderella asked to attend the prince's festival; her stepmom answered:

I have scattered a bowl of lentils into the ashes.

If you can pick them out in two hours, then you may go.

Of course, she picked them out.

But even so, she couldn't go,

for like time, her stepmom was cruel.

Instead, Cinderella, as she did three times per day, went to her mom's grave and prayed beneath the tree:

shake and quiver, little tree, throw gold and silver down to me-

she was given a gold and silver dress the first night, and a more splendid one the second.

Of course, Cinderella fled the festival, fled unknown promises of happily ever after. Had the prince not pursued, her greedy step-siblings wouldn't have shaved off their heels, never snipped off their toes; they wouldn't have had their eyes gouged out in the chapel on Cinderella's wedding day. 
The preschool graduate grew up, learned Cinderella's tale bore more red than white, that Walt Disney offered empty promises of happily ever after, and the brothers Grimm had it right.

But it was not a rich man's wife who died it was the rich man himself who consumed greed in barley-gold.

She grew up

from her dad's ashes, offer it to heathen gods

of her step-siblings-

may they fill her shoes

with their blood.

Of course, her prayer was unheard. like the brothers told; to pick bone

to collect bone in bowls, to cut off the heels and toes 